\title{
WHY THE HELL ARE CUSS WORDS NOT INCLUDED IN TEACHING OF PORTUGUESE AS FOREIGN LANGUAGE?!
}

Manjulata Sharma

Pontifícia Universidade Católica do Rio de Janeiro

\section{ABSTRACT}

This brief study of Brazilian swear words is an attempt to understand the non-inclusion of swear words in the teaching of Portuguese as a foreign language as they are considered as taboo lexicon from the point of view of the institutionalized normative standard language supervised periodically by the Academies. I argue that, since the swear words form a part of the repertoire of popular colloquial vocabulary, they represent the popular culture through their intensity of emotional expression and contextual use. I use the Theory of Lexiculture, proposed by Galisson (1987), and Functional Grammar, by Halliday (2004), to argue that swear words should be introduced through figures of speech such as euphemism and dysphemism, as well as comparisons between swear words of native language of the learner and that of the target language to give the learner a better understanding of the emotional aspect of the language and to foster better pragma-linguistic, sociopragmatic competence and intercultural competence for the learner of Portuguese as a Foreign Language.

KEYWORDS: Cuss words, teaching of Portuguese as PLE, Lexiculture, Intercultural Competence 


\section{Introduction:}

Some years ago, while walking down a street in Lisbon with few friends when I heard someone exclaim angrily, filho da mãe! I was quite shocked by the anger in the voice and asked my friend aside, "Are we all not filho da mãe 'our mothers' children'?" translating the terms literally word to word. She laughed aloud and explained the cultural significance of the expression as a cuss word. That was my first 'lexicultural' shockresult of clash of values and visions.

Few years later, the incident repeated itself in Brazil but this time, with lesser intensity of the 'lexicultural' shock. I had become wiser by then and the shock had become milder. But this did make me think about the reason why the books on Portuguese as a foreign language (PLE) do not include the cuss words that are so frequently used by the native speakers of Portuguese, to express their day-to-day emotions and also to socially bond with friends. As a student of Portuguese language, I knew the dictionary meaning of filho, the preposition 'de' and the meaning of mãe, but not the socio-pragmatic contextual use of these words. I had learnt the grammar and the vocabulary alright minus the cultural aspect that could have given me the intercultural competence in the language to attain an adequate level of communicative efficiency.

The language is a product of culture and reflects not only the thoughts of the speakers, but also their relation with nature and society. This way the cuss words and slang not only demonstrate the evolutionary trajectory of a language, but also the linguistic decadence of a social group. What the 'hell' is a cuss word! Irrespective of social class, age group or gender, cuss words are a part and parcel of discursive practices in the language and culture of Brazil. This becomes clear when an expresident of Brazil, during a speech in the state of Maranhão, says Quero tirar o povo da merda; or in an observation addressed to a research scholar, a professor at a Federal University says - Você está fodida. These are some of the prototypes of commonly used cuss words in circulation even among the higher echelons of Brazilian society to deal with anxious, unexpected situations. It is impossible to avoid dozens of cuss words in music, radio and television programmes. Here is a song by Charlie Brown Jr., the rapper Dogão, a dog in a man's body, created by a producer Rick Bonadio. In the following song, called "Papo Reto" by Charlie Brown Jr., we can see the use of highlighted cuss-words. 


\author{
$[\ldots]$ \\ Ô otário, eu vou te avisar: intelecto de cu é rola \\ Vc falou para ela que eu sou louco e canto mal \\ Que eu não presto \\ Que eu sou um marginal \\ Você falou pra ela que eu sou louco e canto mal \\ Que eu não presto \\ Que eu sou um marginal \\ Que eu não tenho educação \\ Que eu só falo palavrão \\ E pra socialite eu não tenho vocação \\ Que eu não tenho educação \\ Que eu só falo palavrão \\ E pra socialite eu não tenho vocação \\ Sei que isso tudo é verdade \\ Mas eu quero que se foda essa porra de sociedade \\ Pago minhas contas, sou limpinho \\ Não sou como você filho da puta, viadinho. [...]
}

In popular genres of music such as rap, funk etc. one can find a profusion of cuss words in the lyrics. In the past, cuss words were used to deviate the harsh laws of military dictatorship, but today they are used without batting an eyelid and are socially accepted among people of same age group. Nowadays, it is no more common to hear parents admonish their kid and say "Don't use cuss words, son" since the TV actors use lot of cuss words in the soap operas that are viewed by the entire family together as entertainment, and therefore seem to have taken roots in Brazilian popular culture.

Keeping in mind the uninhibited use of cuss words in day-to-day life, irrespective of age and class and gender, a teacher and a learner of PLE, one is inclined to question- why the books on teaching of Portuguese (PLE) continue to keep the taboo language, out of teaching programmes? Why do the non-native learners of PLE do not have the opportunity to learn this popular form of expression that the native speakers use so frequently? In other words, the 'sanitized' teaching manuals of Portuguese for foreigners do not include this popular form of expression that forms an integral part of Brazilian culture thus keeping in dark, the nonnative learners of the language that would otherwise make them more spontaneous, emotive and socially efficient in communication with native speakers. Keeping the taboo vocabulary at bay, turns the teaching of PLE 
into interiorizing a bunch of formal standard grammatical norms instead of a living, vibrant vocabulary that gives vent to emotions of Brazilians in every kind of anxious situation.

Who decides what cuss word is and what is not, depends on the native speakers of a language. One way to decide this depends on the mechanisms of standardization such as textbooks, dictionaries, electronic and print media. This means the written part of language decides what is good and acceptable in verbal language.

This study aims at conducting a linguistic research on the uses of cuss word in Portuguese language in Brazil and explores its relevance in the teaching and learning of Portuguese as a foreign language (PLE) a topic that does not usually find favour with the researchers for being a taboo. Therefore, this could at first instance, sound polemic and controversial for being considered socially offensive by those belonging to a refined culture. Beside this, cuss words are considered a part of colloquial language as slang (baixo calão) and for this very reason do not seem to have neither a definite syntactic structure nor a fixed norm for contextual usage within the language that is considered cultured and acceptable.

Therefore, the teaching manuals neglecting of this part of popular linguistic expression could be due to the taboo to speak these "dirty" words which, according to Santos and Costa (2013, p.01), are "born of necessity of human expression as well as product of a conscious vocabulary and phonetic selection."

In pragmatics, the meaning is generated by the effect produced by usage of speech acts. Therefore, what is important is that the communication and function of the language among its users are based on the processes of inference that can be drawn by understanding the implicit message. At this point, an incident that took place in Delhi University at the time of the festival of colours, Holi, involving a young visiting professor of Italian language who was also fluent in Hindi language and some of his Indian students who, as part of the festivity threw colours on him drenching him completely from head to toe. Outraged by this behaviour, he barged into the staffroom and in presence of some of his colleagues shouted a loud Murkh! (stupid) referring to the students who had thrown colours at him. This expression drew an instant laughter from the colleagues because of the mild nature of that expression and wrong context since it referred to the mental rather than behavioural error of the person. He became even 
more annoyed thinking that everyone was out to have fun at his cost until he was calmed and told the correct word "badtameez (bad mannered) to be used in that particular context. He visibly felt at ease, but not before feeling embarrassed. This shows that despite the excellent proficiency in a foreign language, the day to day reaction to unexpected situations are expressed only through emotionally charged cuss words as a reflex action and their correct contextual usage is imperative for the learner of a foreign language to avoid embarrassment and even misunderstandings. In serious cases, even spoiling a relationship with native speaker can happen due to an innocent error. The importance of correct usage of words in the right sociocultural context pragmatically surpasses their meaning in semantics and syntax.

Thus, it is important that the learners learn the usage of words as used by native speakers, their lexical choices along with restrictions of the use in particular social interactions, and importantly, the effect that the language has on the participants of interaction. Therefore, the pragmatics being the mediator between linguistic use and communicative use proves the intrinsic relation between the language and its communicative context in which it is being used. So, it is important for the learner to acquire pragmatic competence in taboo vocabulary and conventional practices. (THOMAS, 1983) as well as pragma-linguistics given that the language without context does not exist and that the context is created by language given that speech acts are realized in the context. In other words, understanding the speech act in the context, will elicit the right response from the learner in the sociocultural situation in the target language.

\section{Justification and corpus}

In none of the Portuguese Language books for foreigners was found any material dedicated to teaching of usage of taboo vocabulary in communicative situations. Beside keeping the foreign learners at a disadvantage in terms of use of language in social interactions, also reflects marginalization of cuss words are a vocabulary considered taboo. Not being familiar with the cuss words leaves a non-native learner feeling marginalized in a group of native speakers. He is inhibited in his social interactions where cuss words are used like punctuation marks especially amongst youngsters. For example, caralho is used by Brazilians in different contexts of social interactions; to express long distance- lá na casa do caralho or convey something without any significance nem 
por um caralho or to show that he had had enough Ai, meu caralho! The emotive range of cuss words spans from cursing, surprise, shock, indignation, irritation, anger, frustration, to happiness, excitement, euphoria and ecstasy.

\subsection{Corpus}

Due to their taboo status, the institutionalized resources of preservation and propagation of language- dictionary, textbooks, newspapers and other such sources, rarely carry the taboo vocabulary. Thanks to the burgeoning access to communication technology that today sites like Facebook have helped lay bare open the usage of taboo vocabulary for general public and to some extent even the non-native language learners because of many advantages; firstly, the person using cuss word is not visible to the netizens, therefore there is no embarrassment if any, experienced directly between the user and the readers, most of who are faceless. Therefore, the social media has become a fertile ground for usage of taboo vocabulary for exactly the reason they are considered taboo. The corpus for analysis is taken from the most fertile territory of internet website called www. buzzfeed.com compiled by Capanema and published on 11 April 2017, titled " 25 Expressions that prove that the Brazilian is astounded with ass". The advantage in using this as corpus is that it is a most updated text on cuss words that was commented upon the Portuguese speaking netizens from across the globe through the internet, which added some authenticity in terms of their use by commenting on this publication.

\section{Methodology}

In order to investigate the use of cuss words in Portuguese language in Brazilians we will conduct a bibliographic research in books, articles thesis and dissertations in the area of language, culture, taboo vocabulary, lexicology and sociolinguistics.

For building a corpus for research in the definition of cuss word, obscene words or slang will be explored in order to understand the origin of their linguistic taboo and the distinction between the colloquial and standard norm of the language. All the research will be based on linguistic theories, in the attempt to investigate the emotional quotient of the cuss words and how they can be classified. The corpus for analysis is taken from " 25 expressões que comprovam que o brasileiro é cismado com $\mathrm{Cu}$ ”, compiled by Capanema and published on 11 April, 
2017. Finally, in the last part of this study, few suggestions will be offered for inclusion of cuss words in the teaching of Portuguese as a foreign language.

\subsection{Definitions}

According to the definition by Aurelio Dictionary (2005, p.43) cuss words are obscene or crude terms that are a part of a language. In fact, they belong to a group of words considered by the society, as rude and indecent and those when proffered or written, hurt the decency, honesty and integrity of someone, for being offensive, aggressive and immoral. The definition of lexis in the dictionary is $(2005, \mathrm{p} .543)$ a group of words of a language, representing therefore the cultural heritage of people. The speakers of a language are not capable of completely dominating their own native language, due to the basic volatile nature of words being a major difficulty. As for the word taboo, the dictionary defines it as (2005: 831)

Belongs to social sciences. 1. Sub. Mas. Prohibited, for being sacred or ritualistic, of any contact with someone or something that is considered nauseating or impure; sexual taboo, verbal taboo.

\section{The object of this prohibition.}

3. What is prohibited in the individual or social behaviour due to moral or religious reasons either due to superstition. It can be adjective as well.

4 That which is forbidden due to reasons above or should be avoided carefully.

Thus, based on fact that to be human is to be a linguistic and cultural being and that through the medium of language and culture he interprets the world that surrounds him, Camâra Junior (1972, p 273) said "(...) every language seems to be constituting a privileged means of expression, as an extraordinarily rich instrument (...) of thinking, of speaking, of doing and of acting upon the world, the society, on collective and individual life". Professor Orsi (2011, p.335) conceptualizes cuss word as an "item that surpasses the considered limits of good decency and morality, that is why some erotic-obscene vocabulary, especially those referring to sex, can be classified as cuss words". According to the scholar Bono (2008 as quoted in ORSI, 2011, p.335), it is a term, 
"which is unacceptable to social conventions and whose use in public is socially objectionable and therefore censorable". The definitions point to the fact that the taboo words are "product of prohibition", created by the authorities vested with social, moral-ethical and religious powers who see them as nocive and impure, especially in sexual and verbal terms, and therefore should be carefully avoided in an individual's behaviour in public. According to Orsi (in the work cited) "the linguistic taboo has its origin in sanctions, restrictions and social scruples, (...) and develops in the prohibition to proffer or not say certain lexical items to which certain power has been attributed and in case violated shall invite punishment for those who employ it."

Thus, being a predominantly a sociocultural product, the cuss words present synonymic variations which are individual and regional in nature. Some synonyms of cuss words that were discovered during this research ranged from: words, cuss words, synonyms in popular language, reprimand, affronting words, ugly names, obscene words, rude words, expression of aggression, bad mouthing etc. For differentiating cuss words from reprimand, we define the reprimand (xingar) which according to Aurélio is brasileirismo. To hurl insults or harsh words, exchange insults This way it can be clearly understood that cuss words are impregnated with the idea of obscenity, lack of modesty and decency, while reprimand denotes merely insult and that is why the reprimand does not invite sanctions like cuss words do.

\subsection{Dichotomy: Urban/ written vs Rural/ spoken}

Taboo vocabulary being the product of sociocultural censorship, has its origin in the cultural dichotomy mirrored in the language, that in turn is related to social and cultural hierarchy. Eagleton (2000), in his book "The Idea of Culture", traces the historic evolution of culture from its etymologic origin from latin colere that meant to cultivate to modern times, when it means being civilized, passing through the phases of semantic changes due to urbanization. In this sense, the term culture becomes a paradox, when the inhabitants of a city become more 'cultured' with respect to those who till the land in the rural areas. Consequently, the culture took on the "majestic garb" on one hand, and religious authority and power of invasion and occupation. Assuming power, the more cultured took on responsibility of prescribing for the others the linguistic and cultural norms that would prevail over the speech within that society 
through the written word. While the cultural norm operates through an "institutionalized apparatus of reference and distribution" (BARROS, 2005, p. 38) through the dictionaries, grammars and Academies, the spoken language out of these institutions does not have a rigid norm. According to Barros the normative discourse classifies the language on the basis of ethical and aesthetic categories; not on linguistic, but on sociohistorical criteria. This way the good (correct) use contradict the bad (incorrect) use of language by others and therefore distinguish the beautiful from the ugly in the language. Michael Halliday (2004, p.728) cites Matthiessen (2002a) to distinguish between the written and the spoken language saying that, "written version is more complex in terms of lexical density and spoken version is more complex in terms of grammatical intricacy."

In the face of it all, it can be assumed that the process of taboo; turning ordinary neutral words into cuss words is an extralinguistic process, exclusively sociohistorical and cultural based on ethics, aesthetics and morality prevailing in the popular culture of the society considered inferior to the refined culture. In the specific case of Brazil, there seems to be an effort to bring back the popular culture which is considered as the spirit of national culture.

According to Simões of (2004, p. 94), professor at Rio de Janeiro State University, "it is time to rediscover Brazil. It is imperative that Brazil reveals its cultural treasures as a matter of survival: without culture we do not have soul, we are nothing." In her article Simões (in the work cited, p. 95) emphasizes the necessity of a "genuine language practice (as) a factor for cultural preservation" keeping in view, relation between the usage of language and preservation of culture. This dichotomy between day-today popular culture and the erudite culture gives rise to the fundamental question on teaching of language - Which culture and language should be taught to non-native learners of the Portuguese of Brazil?

On this point, Simões (in the work cited, p. 95) believes that, "the language of the salons has never ever managed to reach the speaking masses, and they are historically marginalized by the scholarly linguistic practices. She believes that "it is time to mirror the soul of Brazil in the backwoods, coastal areas and farms, thickets and beaches, 'pampas and pantanais'."

Therefore, learning popular culture means learning of values, customs, beliefs, mentalities, superstitions, taboos, concerns of the native speakers of the target language. In fact, all or any language is a heterogeneous ensemble of variety. In Portuguese of Brazil, the standard 
norm is not the only form of speaking, it is more than a group of linguistic variation based on historical, cultural or political circumstances. Each variation is in fact, a result of particularities of the historical experiences of group of speakers-, and one of the characteristics of human languages is that they are not immutable; they undergo changes constantly-slow and continuous without being perceptible even to the native speakers. These changes can be permanent and there does not seem any way to stop these changes. Therefore, the teaching of foreign language should include not only the standardized norms of the language but also the day-to-day experience of the native speakers and their emotions that are expressed through cuss words or slang. This belief finds base in the theory of lexiculture that will be defined and discussed in the next section.

\section{Theoretical Assumptions}

Learning a foreign language entails, besides a good knowledge of grammar and vocabulary, a fair amount of acquaintance with culture of the target language, keeping in view that the vocabulary is an integral part of cultural and historical heritage of a society that allows people to communicate and have a social and linguistic identity, which is distinct and immutable. This way, here an attempt will be made to show how vocabulary acts as window to Brazilian culture, considering that besides their literal meaning, it also reveals other multiple meanings, which are gradually incorporated into the society through sociocultural habits.

To this study of cultural dimension, Galisson (1987) lent the term lexicultura and to the cultural quotient of the vocabulary, he termed as Carga Cultural Compartilhada (CCC). The concept of Functionalism focusing on functions of the language by Halliday (2014). Through presentation of these concepts we shall carry out an analysis, observing the use of cuss words in context of teaching of Portuguese as (PLE).

The Functional Grammar of Halliday (2004) proposes three function of language as the fundamental functions: the ideational function, through which the speaker and the listener organize and incorporate their experiences of the reality of the world in the language; the interpersonal function, through which social roles are established and maintained; and the textual function, that deals with the contextualization of the linguistic units. The three functional components of meaning, ideational, interpersonal and textual are realized throughout the grammar of a language. (in the work cited, p.361) 
Traditionally the teaching of a foreign language consists of two principle components: vocabulary and grammar. In rigorously following this pattern, the culture gets completely marginalized. This gap between grammar and vocabulary was bridged by Galisson's theory of lexiculture in 1987. As a concept, lexiculture is the access to study of lexis that is culturally marked. Amongst other aspects, lexiculture shows us the uniqueness and the diversity of places where culture in a language can be found, for, we know that the lexis at the level of linguistic description directly linked to the extralinguistic reality. This means that the language as a depositary of culture where the lexis (léxico) leads us to the word (palavra) which is an ensemble of words of the language carries. According to Barbosa $(2009$, p.34) the word with CCC is closer to the popular live culture of daily life than the erudite institutionalized culture that is taught in institutions of learning and regularly revised by Language Academies. This distinction between the dichotomy of two culture is often termed as 'cultura de salão' and 'cultura de sertão'.

For Halliday $(2004$, p. 07), "[...] ]all writing systems are in origin parasitic on spoken language [....]" Even with the deaf for whom the first sign of language is the visual written language, sign according to him is more analogous to spoken than the written language. The cuss words are lexicultural primarily spoken words invested with intense emotions to

\section{Data Analysis}

In a study, titled Pragmatics of Swearing, Jay and Janschetz (2008, p.267) discovered that cuss words serve to express emotions generally and anger and frustration in particular. The researchers described how much the degree of intensity must be learnt and contextual factors depend on the social interaction and the relation between the interlocutors. In interpersonal relations, the cuss words could even strengthen the relations with their emotional quotient.

The Brazilian author Luiz Fernando Veríssimo (1992) in his weekly column in O Estadão de São Paulo newspaper says, "Brazilian is expansive but at the same time is modest about his feelings." He prefers to denominate the offensives exchanges between friends as insulto carinhoso, or selvageria amorosa as a national institution; that can be roughly translated as the 'endearing insult' or 'lovely savagery'. The author describes a typically Brazilian way of two male friends meeting after a long time in the street, hurling insults on each other directed at their own mothers. 
- Mother fucker! Boor! (Filho da mãe! Cafajesta!)

- Your mother is still in the prostitution area? (Sua mãe continua na zona?)

- Learning from yours. (Aprendendo com a sua.)

- Give me a hug. (Dá cá um abraço.)

The author says that mother is the last Brazilian taboo, which he exemplifies through the friendly conversation above. They hug among throaty laughter (Se abraçam às gargalhadas), not before exchanging few more endearing expletives like Crápula, Vigarista! Farsante!, amongst pats, punches, blows on the back until this savage love turns into a fist fight. The article demonstrates the range of emotions expressed oscillating between two extremes; from extremely positive to extremely negative.

In the Holy Bible (Saint Mathews, 15-18), is an example of relation between emotions and words: What comes out of mouth comes from the heart". The cuss words according to Tartamella (as quoted in ORSI, 2011, p.334) "are lexical units shot like verbal projectiles" and act like "cathartic elements in lessening the social tension." This is evident during highly charged sports events like football matches, competitions and Olympic games or other events, or unexpected, undesirable painful events like bad news, a sudden fall for example; Merda! Bati a perna contra mesinha!

The cuss words also reveal who we are and our place in the world. According to 'Pragmatics of Swearing ', mentioned above there is a strong relation between the use of cuss word and the one who proffers it. The site www.buzzfeed.br presents different situations of communication for speaking cuss words, out of which twenty-five are on "cu" as given in the table below, titled " 25 expressões que comprovam que o brasileiro é cismado com cu" ( 25 Expressions that prove that Brazilian is Astounded by Ass).

Table $01-25$ expressions that prove that Brazilians are astounded by ass.

\begin{tabular}{|l|l|l|}
\hline & $\begin{array}{l}\text { FUNCTION IN COMUNICATIVE } \\
\text { SITUATION }\end{array}$ & CUSS WORD \\
\hline 1 & Para encerrar qualquer discussão & Teu cu! \\
\hline 2 & Como é bom & Ficar louco do cu. \\
\hline 3 & Tem tanta coisa que & É de cair o cu da bunda \\
\hline 4 & Há horas em que é inevitável & Ficar com o cu na mão \\
\hline 5 & Mas hoje você está com & Fogo no cu \\
\hline
\end{tabular}




\begin{tabular}{|l|l|l|}
\hline 6 & $\begin{array}{l}\text { Espero que você nunca tenha co- } \\
\text { mido nada }\end{array}$ & $\begin{array}{l}\text { Pior do que carne do cu feita no } \\
\text { fogo da lamparina }\end{array}$ \\
\hline 7 & Isso aí & Arrepiou até os cabelos do cu \\
\hline 8 & Esta situação & É de foder o cu do palhaço \\
\hline 9 & É como diz o ditado & $\begin{array}{l}\text { Passarinho que come pedra } \\
\text { sabe o cu que tem }\end{array}$ \\
\hline 10 & Mas vem cá & $\begin{array}{l}\text { Que que tem a ver o cu com as } \\
\text { calças? }\end{array}$ \\
\hline 11 & Isso aí fica lá & No cu de judas \\
\hline 12 & Putz & Azedou o cu do frango \\
\hline 13 & Aprende uma coisa & Merda cagada não volta pro cu \\
\hline 14 & Não é prudente & $\begin{array}{l}\text { Contar com o ovo no cu da ga- } \\
\text { linha }\end{array}$ \\
\hline 15 & Hoje eu vou dormir & Até o cu fazer bico \\
\hline 16 & Um momento de sabedoria & $\begin{array}{l}\text { Quem aluga o cu não se senta na } \\
\text { hora que quer }\end{array}$ \\
\hline 17 & O pessoal só quer saber de & Encher o cu de pinga \\
\hline 18 & Um conselho & Vai coçar o cu com serrote! \\
\hline 19 & Ó numa boa & Vai tomar no cu tranquilo! \\
\hline 20 & Não faz sentido & $\begin{array}{l}\text { Dar um tiro no cu só para aprovei- } \\
\text { tar o buraco. }\end{array}$ \\
\hline 21 & Olha a diquinha! & Enfia o rojão no cu e sai voando! \\
\hline 22 & Ou então & Vai arrastar o cu na brita! \\
\hline 23 & Interessante hein? & $\begin{array}{l}\text { Enfia um peixe no cu e diz que é } \\
\text { sereia }\end{array}$ \\
\hline 24 & É o seguinte & $\begin{array}{l}\text { Bota uma dentadura no cu e vai } \\
\text { sorrir pro caralho }\end{array}$ \\
\hline 25 & Ah é assim? Então & Enfia no cu essa merda! \\
\hline
\end{tabular}

The 'cu' (ass) related cuss words could be explained perhaps by what Preti (1984, p.124) terms as 'metáforas de natureza', which highlight the objects by some of its particular aspect and invest it with emotions. Since the people who use them have limited vocabulary they choose one of the properties (like form, colour, smell or sound etc.) to compare with a common phenomenon in daily situations. In choosing the 
property of 'cu' as the idea of an abyss, crack, cave, aperture to a long channel, corridor, tube etc. highlights the perception of length, depth, bottom of a long channel. Therefore, when the expression of a deep and long felt emotion is needed to be expressed, the popular term sees the 'cu' is to be the last word, as metaphor for intensification of emotion by the native speakers.

All the languages, irrespective of race, religion or gender, have a big repertoire of abundant and varied cuss words. To investigate the habit of proffering cuss words in general, the human behaviour scientists decided to find out the reason behind the need to speak cuss words with intensity and consistency. It was found, without any shred of doubt that when proffered with spontaneity, intensity and charged with emotions of those who speak the cuss words, the curses and damning have the power almost immediately, to alleviate the tension. Moreover, badmouthing can be introduced to cure the physical and mental ailments that originate, most probably through suppression of these very tensions. Thus, cuss words express the intensity of emotions of their speaker in the way that the neutral words or the cultured language do not. Being an expressive society, Brazilians do not hesitate to curse and others their emotions or the enormity of their pain and sacrifices ranging from delay in arrival of bus at bus stop to the rising prices to Brazil losing the world Cup.

\subsection{Classification of Brazilian Cuss words}

Owing to the flexibility in usage, context and range of emotions, it is an uphill task to classify cuss words. But Pinker, in his book "The Stuff of Thought" (2007: digital version), says the origin of aggressive words and the repercussions related to its use can be traced to religion, referring to the Holy Bible, more precisely to Levitico 24-16, that says “ Those who blaspheme the name of the Lord shall surely be put to death; all the congregation shall stone him: as well as the stranger, as he that is born in the land when he blasphemeth the name of the Lord, shall be put to death". In Genesis 2-3, Adam fell because he had sexual relation with Eva despite God forbidding him to do so. Thus, sex was stigmatized by the Catholic Church creating the vocabulary on sex and sexuality a taboo. With passage of time sex and sexual organs; masculine as well as feminine apparently dominate the universe of Brazilian cuss words. To classify the cuss word, the Harvard Professor Steven Pinker (2007) explains the emotions rooted in each cuss word 
Humans just don't entertain ideas, but they steep them with emotions. They stand in awe of their deities, their parts and possessions, and supernatural realm they control. They are terrified by disease, death and infirmity. They are revolted by bodily secretions. They take a prurient interest in sexuality in all its variations. They loathe enemies, traitors and subordinate peoples. As unpleasant as these thoughts are, people willingly inflict them on one another, sometimes to inflict or to denigrate them, sometimes to get their attention, sometimes to show they can willingly endure the thought. As humans make it through the day, they react emotionally to its ups and downs, especially its frustrations and setbacks and sometimes advertise its reaction to others.

According to Pinker (2007), the categories of cuss words deal with religion or supernatural, diseases and infirmities or body secretions, sexuality and its euphemism, the animosity or rivalry, treason and its variants, pains and frustrations. These are main categories that are part of daily routine of people and, to tide over the unpleasant humdrum of turbulence the use of cuss words brings a cathartic relief for the individual. While going over "25 expressões que comprovam que o brasileiro é cismado com cu" one notices that the expression of cuss words is short and demonstrate a rough pattern.

Thus, it is possible to classify them according to their syntactic structure. As a small sample of their structure, we shall include 13 expressions on 'cu' sent in by contributing netizens of the site where this research was conducted.

Table 02 - Possible Categories of Cuss words based on syntactic structure

\begin{tabular}{|l|l|}
\hline Category & Structure \\
\hline Interjective Locutions & Teu cu! \\
\hline Que + Interjective Locutions & Que desgraça da porra! Que bosta! \\
\hline $\begin{array}{l}\text { Imperative of verb ir,enfiar+ } \\
\text { interjection }\end{array}$ & $\begin{array}{l}\text { vai cagar no mato! } \\
\text { vai tomar no cu tranquilo! } \\
\text { vai arrastar o cu na brita! } \\
\text { vai coçar o cu com serrote! } \\
\text { vai dar meia hora de cu! } \\
\text { enfia no cu essa merda! } \\
\text { enfia um rojão no cu e sai voando! } \\
\text { enfia um peixe no cu e diz que é sereia! }\end{array}$ \\
\hline
\end{tabular}




\begin{tabular}{|l|l|}
\hline Prepositional Phrases & no cu de Judas, fogo no cu. \\
\hline Popular Expression. & $\begin{array}{l}\text { ficar louco do cu, contar com o ovo no cu da } \\
\text { galinha, ficar com cara de cu, encher o cu de } \\
\text { pinga, comer cu de curioso, pôr o cu a prêmio, } \\
\text { dar o tiro no cu só pra aproveitar o buraco. }\end{array}$ \\
\hline Interrogative Expression. & $\begin{array}{l}\text { Nasceu com o cu virado pra lua? } \\
\text { Que que tem a ver o cu com as calças? }\end{array}$ \\
\hline a) Verb + Popular Expression & $\begin{array}{l}\text { Arrepiou até os cabelos do cu, azedou o cu do } \\
\text { frango, trancou o cu que não passa nem wi-fi, } \\
\text { tirei a cerveja do cu da foca. }\end{array}$ \\
\hline b) Proverb & $\begin{array}{l}\text { Quem aluga o cu não se senta na hora que } \\
\text { quer. } \\
\text { Quem tem cu tem medo. } \\
\text { O cu do bêbado não tem dono. } \\
\text { Merda cagada não volta pro cu. } \\
\text { Passarinho que come pedra sabe o cu que tem. } \\
\text { Pimenta no cu dos outros é refresco. } \\
\text { Se cabelo for importante não dava no cu. }\end{array}$ \\
\hline
\end{tabular}

As can be seen in the table given above, 'no cu' or 'enfiar + noun + no cu (insert in the ass); the preposition no conveys the idea of aperture or orifice or a long channel. Arguably, mouth too could have been an option, but since it is not an organ directly related to sex, 'cu' is the word used to cause maximum shame and embarrassment to the victim. Therefore, due to the frequency of daily discursive practice in Portuguese of Brazil, "cu" can be designated as a lexicultural term, a culturally charged (CCC) word that shows popular culture and its perception of body and of sexuality. The other culturally charged lexiculture words are the male and female sexual organs; penis and vagina. In a study, conducted by Eliane Braga and Paulo Ribeiro, called "Palavras, Palavrões e Repressão Sexual", they collected 408 synonyms for penis and 484 names for vagina, just from five regions in Brazil; South, Southeast, Centre, West and Northeast. The most frequent word quoted for penis happened to be "pau" (106 times) and the most frequently cited word for vagina was perereca. Here it should be kept in mind that the scientific names used for naming sexual organs are 
not classified as taboo. Oliveira (2008: 118) explains this in following words:

The scientific names of sexual organs are emotionally neutral lexical terms, compared with their colloquial synonyms (cuss-words) that, besides referring parts of the body as certain taboo of our culture, are charged with intention to scandalize, offend express irreverence etc. These are the ones, therefore, in true sense pejorative.

Therefore, the different names used to refer to sexual organs, take on a pejorative tonality both towards "affective appeal" as well as "emotional appeal". There is a tradition of disdain for sex carried by popular expressions and for this reason the denominations for sexual organs are used as insult. Calvino (2009, p. 336) explains that "in identifying the cuss word, it was found that not all the synonyms are cuss words, since some of them could be used to veil, or relieve emotions related to sex". Barbosa (2009) states that sexuality is shown to be manifest in all presentable forms; by aseptic euphemism of scientific or pedagogical discourse, or through the ugliness of pornographic discourse.

This fact is reinforced by a website theToptens the most voted cuss word by the netizens is the $\mathrm{F}$ (-uck) word followed by $\mathrm{C}$ (-unt) for vagina and the third most voted was $\mathrm{S}$ (-hit). Whatever may be the ranking or frequency of the usage, the fact is that cuss words use the vocabulary of sex or sexuality, in order to relieve the pent-up emotions, for example; anger; F(you); depression; F (me); excitement F (yeah); shock Holy F; fear Oh F etc. The online website www.buzzfeed.com has presented the difference between the speakers and non-speakers of cuss words along with communicative situations:

Table 03 - Difference between people who don't speak cuss words and who do.

\begin{tabular}{|l|l|l|l|}
\hline & $\begin{array}{l}\text { Comunicative } \\
\text { Situation }\end{array}$ & $\begin{array}{l}\text { People who don't } \\
\text { speak cuss }\end{array}$ & $\begin{array}{l}\text { People who speak cuss } \\
\text { word }\end{array}$ \\
\hline $\mathbf{1}$ & $\begin{array}{l}\text { Encontrando um } \\
\text { grande amigo }\end{array}$ & $\begin{array}{l}\text { Beleza-super beleza } \\
\text { e você? }\end{array}$ & $\begin{array}{l}\text { Como é que tááá arrombado } \\
\text { do caralho- tô bem porra cê } \\
\text { sumiu hein filho da puta -teu } \\
\text { cu!! }\end{array}$ \\
\hline $\mathbf{2}$ & $\begin{array}{l}\text { Se a comida está } \\
\text { boa }\end{array}$ & Muito delicinha. & Tá bom pra caralho! \\
\hline
\end{tabular}




\begin{tabular}{|l|l|l|l|}
\hline 3 & $\begin{array}{l}\text { Falando mal de } \\
\text { alguém }\end{array}$ & $\begin{array}{l}\text { Aí ele é meio chati- } \\
\text { nho né? }\end{array}$ & $\begin{array}{l}\text { Vix! essa á é um baita de um } \\
\text { pau no cu do caralho!! }\end{array}$ \\
\hline $\mathbf{4}$ & $\begin{array}{l}\text { Irritado com es- } \\
\text { portes }\end{array}$ & $\begin{array}{l}\text { Eita nóis esse time é } \\
\text { dose hein realmen- } \\
\text { te não tem a menor } \\
\text { condição. }\end{array}$ & $\begin{array}{l}\text { Ôô bucetaaa!! como é que } \\
\text { o filho da puta me erra uma } \\
\text { dessas. olha o salário que } \\
\text { esse arrombado ganha pra } \\
\text { me fazer essa porra!! }\end{array}$ \\
\hline $\mathbf{5}$ & $\begin{array}{l}\text { Batendo o dedi- } \\
\text { nho do pé na me- } \\
\text { sinha do centro }\end{array}$ & Aaa como dói! & $\begin{array}{l}\text { Puta que pariu!! Quem foi o } \\
\text { filho de uma puta que deixou } \\
\text { essa porra no caminho? eu } \\
\text { vou pegar uma bazuca e dar } \\
\text { um tiro no meio do cu dele! }\end{array}$ \\
\hline
\end{tabular}

In the examples given above we see the use of colloquial popular abbreviated forms of speech such as tá (está), cê (você), pra (para) and cuss words since we already mentioned above that the cuss word originate and are predominantly a popular phenomenon and is a part of verbal language.

The profusion of interjections in written text demonstrate the intensity of emotional expressivity of cuss word. Here there is the regionalism as well manifested in the interjections like Eita! and Vix! characteristics of northeast of Brazil. According to Halliday (2004, p.426) "the interjections are termed as protolinguistic remnants in adult language."

\section{Lexicultural difference- Indian and Brazilian Cuss words}

It is not our objective to compare the cuss words proffered in India and Brazil, but to demonstrate the that they are the direct product of the vision and perception of the people of the same reality and for this we shall consider the animal cow ( $v a c a$ ) with which India is usually associated and stereotyped with a positive connotation. In Brazil, cow becomes a cuss word with a pejorative connotation many times. From a culture where cow symbolizes positive human values of generosity, love, sympathy, beauty, prosperity and affluence, the animal in Brazil is loaded with negative connotations, especially, when referred to a woman meaning a prostitute. In this respect, Santos and Costa (2013, p.339) point 
to that "the semantic force of this type of vocabulary (...) comes from its negative connotations for intensifying the adverbs and the adjectives or through this force comparing other noun to it, giving it an equally strong meaning that was intended to be given by something positive." This is evident in the dictionaries of Portuguese, Academia Brasileira de Letras (ABL) Dictionary (2008, p. 1270), entry for vaca presents, "Fêmea do touro; mulher devassa ou leviana." Thus, the ABL, that is considered prestigious competent authority on Portuguese language presenting these adjectives for women, shows the cultural values of society. Other dictionary such as Aurélio too presentes the meaning as mulher disforme ou muito gorda, mulher considerada desvergonhada, homem indolente nada excitável; while the online dictionary Michaelis presents the vaca as, "Mulher devassa." The online Houaiss Dictionary too comes with something similar as "mulher devassa despudorada, aquela cujos seios são grandes e caidos."

Professor Dino Preti illustrates how the network of metaphors are composed on the base of a base-metaphor sharing between themselves a semic similarity that allows the speaker to have a precise idea of the reality being communicated. He demonstrates this through the diagram on prostitution, where the cow is a lexicultural word with CCC. Therefore, the cultural symbolism implicit in cuss words should be carefully explained in context to the non-native learner of Portuguese especially from India where some animals are considered sacred and others are considered offensive. At this point, it needs to be mentioned that recently a Brazilian girl addressed an Indian boy as gato, who was highly offended on being compared to a cat. But this Brazilian did not know that had she lovingly addressed him as 'lion' or 'tiger' the Indian boy would have been extremely pleased and the friendship would have been strengthened.

Steve Pinker (2007), professor of linguistics at University of Harvard, makes a special mention to the conceptual metaphor of the verb in Portuguese "comer" which, besides the literal meaning "to eat", means to have sex, which reminds of the Brazilian. Anthropologist Roberto DaMatta (1984, p.40) who explains that the food is associated with sex in such a way that the action of eating can be associated with action of having sex, to encircle, to cover, to swallow, to digest, or circumscribe completely that what was eaten. Therefore, "comer" is a word laden with CCC and should be explained to the non-native learner and especially from India where food has a religious cultural value, so that he understands the right 
context so as to develop the correct understanding of Brazilian culture and does not get shocked when someone says "Ontem comi Rosa."

How the cultural values and perception of the society is reflected in words with CCC became amply clear through the examples cited above. The sociocultural impact of connotation of the word vaca is evident in the large number of weight loss clinics, gymnasium displaying advertisement and other social media channels offering a quick desired weight loss in a short span for a huge fee. This cuss word vaca reserved only for women, is more than evident; in variety TV programmes where young girls in perfectly chiselled bodies dance in the back ground, in sharp contrast to old, wrinkled out of shape male presenters of the programme, as well as in soap operas (telenovelas) churned out by the Globo TV network soap factory. In one such telenovela "Força do Querer (16/09/17), on being asked to stop dating the drug peddler, Rubinho, the actress, named Carine, replies defiantly to her aunt, "By the way, do you have anyone who can provide me with the silicon that I want so much? You don't have, aunty." In a culture where body is considered a capital and all efforts are invested to have a perfectly proportionate body, the word 'silicone' becomes a word with CCC. This aspect of Brazilian culture is evident in the second ranking for highest plastic surgery conducted after the United States.

\section{Cuss words in teaching of Portuguese as foreign language}

Due to the emphasis on teaching the standardized form of the language, seen as cultured language, the cuss words are excluded from the teaching of PLE for being a part of informal, colloquial or uncultured language as part of popular culture. The well-known academician Evanildo Bechara recommends the use of popular language since it is in this language that the popular culture gets reflected, whereas in, the cultured form, it becomes rationalized and therefore becomes lifeless devoid of any colour.

Leffa (2000, p.37), through Tréville and Duqette (1996), consider a word incomplete until it is in the company of its privileged co-occurrences based on cultural implications. The author cautions us on the negligence of cultural aspect, especially concerning the teaching of foreign language, where the learner does not have any knowledge about the culture of the target language. Leffa bases his proposal on the concept of lexiculture of Galisson. 
In a research, carried out in the post graduate Studies of Language (PPGEL) in PUC-Rio, on expressions of aggression and its applicability to PLE, the researcher Gláucia Torres (2015) believes that the relation between mother language (LM) and the affect generated since "the first words" by an individual is a determining factor in formation of the vision of the world, of desires, of likes and dislikes. Therefore, in acquisition of a foreign language (LE), the learner has to adopt to a completely new reality, and a new vision of the world from the point of foreign language that is very different from his own.

The process of familiarization of the foreign language takes place, generally through the methods conceived arbitrarily, without taking into consideration the culture of the learner. The teaching manuals of PLE for learners in Argentina may work fine, but in India it may not find success due to the vast cultural differences. In other words, the learner fails to develop affection for the foreign language. In this sense, in my opinion, the cuss words are words with CCC and represent the intensity of emotions of the speakers in the LE. Therefore, its use should be explained to the non-native learner in context, so that he can familiarize himself closely with concerns, emotions, superstitions, taboos, prejudices, beliefs and customs of the native speaker of the target language, and in this way, gradually build up affect and proximity to the LE. Otherwise, he continues to think of the language in terms of lexico-grammatical form associating the suffix '-ão' as augmentative in case of palavrão, as being a word that is big and difficult but not offensive. This view can be taken permanently during the process of learning till the point the learner encounters a cuss word in his book of PLE.

Being so, the words with CCC mirror values, attitudes and concerns of the native speakers in a daily culture, being loaded with emotions and affect. Now, the contextualized use of these in day-to-day interactions aims at maintenance of interpersonal relationships, which the learner of PLE tries to adopt when integrated into it. Therefore, for better integration in the adopted culture, the teaching of cuss word should be encouraged. I propose the introduction of cuss word through two figures of language -euphemism and dysphemism.

What makes a cuss word different from its synonym in the cultured language? Steve Pinker (2007, p. 398) answers this question by pointing to euphemism and dysphemism. The former is understood as an act of making an idea less offensive, by substituting it with a word or an expression 
less unpleasant. Dysphemism is opposite of euphemism, where there is a substitution of a normal term by a more offensive ones evoking strong and negative emotions or even attracting attention by the aggression of the word.

Table 04 - The Emotional and Cultural CCC Words: Neutral, Euphemism and Dysphemism andTaboo

\begin{tabular}{|l|l|l|l|}
\hline Neutral word & Euphemism & Dysphemism & Taboo \\
\hline Excremento & coco & porcaria & Merda! \\
\hline Penis & Órgão sexual masculino & Pau, pinto & Caralho! \\
\hline Vagina & Órgão sexual feminino & perereca & Buceta! \\
\hline
\end{tabular}

Therefore, it is dysphemistic to refer to someone by the part of the body, or by physical traits. The learners should be informed of the sociocultural context of the usage of cuss words.

\section{Final Considerations}

Using cuss words is a universal phenomenon irrespective of language, culture or age group. Highlighting the advantages of cuss words Preti (1984, p.77) says that through the centuries undoubtedly, this language has been a compensatory cathartic element to counter all moral and social pressures faced by man. In this context, Sérgio Luís de Carvalho (2014), the author of Dictionary of Insults", on Twitter page of BBC says that, "Insulting is important. It is a sauna for the soul. It brings relief. We all need to do this off and on. If one does not do it, there has got to be a problem there." In line with the idea of Arango (as quoted in ORSI, 2011, p.) considers that "Besides show casing a culture, obscene words reveal essence of human being. In fact, in it he expresses in a most pure and transparent way, rid of any veils and any modesty, the mysterious instinct that exists since the origin of life itself."

Thus, we here examined the importance of taboo vocabulary of cuss word in the teaching-learning of portuguese as PLE, from my perspective as a foreigner in Brazil. Words with CCC, such as $\mathrm{cu}$, caralho, porra, merda, foder, for example with their euphemism and dysphemism will open up for a learner a world of new perceptions, conventions and visions that are so different from his own.

During my research, I discovered that there are two different variants 
of insults: one is crude and the other extremely cultured, elegant and erudite. According to Sergio Carvalho (BBC.com:2018) instead of calling someone 'estupido', one can also address him as 'acéfalo', 'traiçoiro' can be called as 'insidioso', ladrão' as 'flibusteiro' and 'burocrata' as 'mangade-alpaca'. A person who suffers from syphilis, in an erudite way, can be said 'ter mal secreto' and if someone does not heed you then he is “mоисо'. Luis Milanesi in BBC.com (2018) quotes some refined cuss words; for example, onagro (ass) mentecapto (idiot) sevandija (one who lives off the expense of others). Therefore, the subject surprised me by its depth and passions it evokes in Brazilians. Given that it is in taboos that the essence of human life in terms of attitudes, relation between sexes, sexuality and different other aspects of Brazilian language and culture are rooted.

The teaching of taboo vocabulary, will lend undoubtedly, a better intercultural understanding and will facilitate and enable a better dialogue between the non-native learners of the Portuguese language and the native speakers, keeping in mind the ever increasing facility of easy access to technology of communication and the development of various platform of dialogue, netizen forums, chat-rooms and others social media Apps like twitter, Instagram, Facebook etc., where the youth are always looking to learn and socialize with youth in other part of the world in a language that he or she wants to learn. The internet has become a very fertile ground for cuss words since it guarantees complete anonymity and therefore, safety from legal repercussions. It is time that the teaching of foreign language takes note of sociolinguistic changes in society and includes the taboo vocabulary a wholesome view of the throbbing target language instead of a sanitized, impractical and insipid version. 


\section{POR QUE DIABOS PALAVRÕES NÃO SÃO INCLUÍ- DOS NO ENSINO DE PORTUGUÊS COMO LÍNGUA ESTRANGEIRA?}

\section{RESUMO}

Este trabalho tem intuito de investigar a exclusão dos palavrões brasileiros no ensino do português como língua estrangeira por serem considerados vocabulário tabus do ponto de vista da língua normativa institucionalmente padronizada e periodicamente supervisionada pelas Academias. Eu pressuponho que desde os palavrões formam o repertório do léxico coloquial popular, eles representam a cultura popular através da intensidade da expressão afetiva e o uso contextual. Eu pretendo utilizar a Teoria de Lexicultura de Galisson (1987) e Gramática Funcional de Halliday (2004) para afirmar que os palavrões devem ser apresentados através de ato da fala como eufemismo e disfemismo bem como através de estudos comparatistas entre a língua-alvo e a língua materna, para apresentar ao discente uma compreensão melhor do aspecto emotivo da língua com o intuito de fundar nele a noção de competências pragma-linguística, sócio pragmática e interculturais do PLE.

PALAVRAS-CHAVE: Palavrões, Ensino de português como PLE, Lexi-cultura, Competência Intercultural,

\section{REFERENCES}

ALÉONG, Stanley. Normes linguistiques, normes sociales: une perspective athropologique. In: BÉDARD, Édith et MAURAIS, Jacques. La norme linguistique, Troisième partie. Available at <www.cslf.gouv.qc.ca/bibliotheque-virtuelle/ publication/html/?tx iggcpplus pi4\%5bfile $\% 5 \mathrm{~d}=$ publications $/$ pubf101/f101p3. html\#ix. $>30$ Set. 2017.

BARBOSA, L.M. de Assunção. O conceito de lexicultura e suas implicações para o ensino-aprendizagem de português língua estrangeira. Filologia e Linguística Portuguesa. $n^{\circ} .10-11$, p.31-41, 2009. 
BECHARA, Evanildo. A língua como fator de identidade. In: VALENTE, André (Ed.) Língua Portuguesa e Identidade: marcas culturais. Rio de Janeiro: Editora Caetés, 2007.

BRAGA, E. R. Maio, RIBEIRO, P.R. Marçal. Palavra, Palavrões: um estudo sobre a repressão sexual a partir de linguagem empregada para designar a genitália e práticas sexuais, na cultura brasileira Available at $<$ http://www.anped.org.br/sites/ default/files/gt23-4982-int.pdf. $>23$ Set. 2017.

BRAGA, Eliane R. M, RIBEIRO, Paulo, R. M. Palavras. Palavrões - Um estudo sobre a repressão sexual a partir de linguagem empregada para designar a genitália e práticas sexuais, na cultura Brasileira. Available at $<$ http://www.anped.org. br/sites/default/files/gt23-4982-int.pdf>

CALVINO, Ítalo. Una Pietra Sopra. Milano: Mondadori, 2009.

CAPANEMA, Rafael. 25 Expressões que provam que o brasileiro é cismado com cu. Available at $<$ https://www.buzzfeed.com/rafaelcapanema/expressoescom-cu?utm term=.yfX4wGa5X\#.erwlaPWqb $>$ 06/08/2018

CARVALHO, Sérgio Luís. Dicionário de Insultos: a estranha origem e a bizarra dos insultos portugueses. Planeta: Portugal, 2014.

DAMATTA, Roberto. O que faz o Brasil, Brasil?, Rio de Janeiro: Editora Rocco, 1986.

EAGLETON, Terry. A Ideia de Cultura. São Paulo: Editora UNESP, 2005.

FERREIRA, Aurélio Buarque de Holanda. Dicionário Aurélio Júnior: dicionário escolar da Língua portuguesa, Editora Positivo, Curitiba, 2005.

GALISSON, Roberto. Accéder à la culture partagée par l'entremise des mots à CCP. Études deLinguistique Apliquée, 67, 1987, p. 109-151

GUILLÉN DÍAZ, Carmen. Une exploration du concept «lexiculture» au sein de la Didatique des Langues Cultures. Available at: https://revistas.ucm.es/index.php/DIDA/article/viewFile/DIDA03031101054/19413. 19 Set. 2017

HALLIDAY, Michael. Halliday's Introduction to Functional Grammar. Great Britain: Arnold Hodder, 2004.

JAY, Timothy, JANSCHEWTZ, Kristin. The Pragmatics of Swearing. Journal of Politeness Research, 4, pp 267-288. Available at <http:/www.mcla.edu/Assets/MCLA-Files/Academics/Undergraduate/Psychology/Pragmaticsofswearing.pdf $>21$ DEZ. 2017.

LEFFA, Vilson. J (Ed.). As palavras e sua companhia: o léxico na aprendizagem. Pelotas: EDUCAT, 2000.

MILANESI, LUIS. Dicionário Brasileiro de Insultos. São Paulo: Ateliê Editorial, 2002. 
OLIVEIRA, H. Fonseca de. Conflito entre a natureza pejorativa ou melhorativa das escolhas lexicais e a orientação argumentativa do texto. In: HENRIQUES, C. Cezar \& SIMÕES, Darcilia (Ed.). Língua Portuguesa, Educação \& Mudança, Rio de Janeiro: Editora Europa, 2008. p.116-122.

ORSI, Viviane. Tabu e preconceito linguístico. ReVEL, v.9, n.17, 2011.

PINKER, Steven. The Stuff of Thought: language as a window into human nature. New York: Penguin Books, 2007. Available at http://us.penguingroup. com. 07/09/17.

PRETI, Dino. A Linguagem proibida: um estudo sobre a linguagem erótica. São Paulo: T. A QUEIROZ Editora, 1985.

ROSE, A., VALE, N., Cabral, A. Pedro. Dirty Portuguese: Everyday Slang from "What's Up" to "F*\%\# Of. Berkely, CA: Ulysses Press, 2010.

SANTOS, D. Cruz, COSTA. K. R. Lopes. Palavrão: Um olhar sobre o possível não arbitrariedade deste signo linguístico. Available at $<$ www.sociodialeto.com. br> 20/08/2018

SIMÕES, Darcilia. Língua portuguesa e cidadania: uma perspectiva multidialectal para o ensino. In: Henriques, Claudio Cezar; Simões, Darcilia (Eds). Língua e cidadania: novas perspectivas para o ensino. Rio de Janeiro: Editora Europa, 2004. p. 94.

TORRES, Glaúcia. T. Ubaldo. O emprego de expressões de agressividade e sua aplicabilidade no ensino de português para estrangeiros. Available at < https://www.maxwell.vrac.puc-rio.br/29463/29463 14/09/17>.

VERISSIMO, Luis Fernando. Amigos. O Estado de S. Paulo. São Paulo, $09 / 11 / 1992$

WIERZBICKA, Anna. Emotions across languages and cultures: diversity and universal. Cambridge: Cambridge University Press, 1999

Recebido: 30/042018

Aceito: 14/09/2018 